\title{
Synthesis of isoindole and benzoisoindole derivatives of teicoplanin pseudoaglycon with remarkable antibacterial and antiviral activities
}

\author{
Attila Sipos ${ }^{\text {a,* }}$, Zsolt Török ${ }^{a}$, Erzsébet Rőth ${ }^{a}$, Attila Kiss-Szikszai ${ }^{b}$, Gyula Batta ${ }^{b}$, Ilona Bereczki ${ }^{a}$, \\ Zsolt Fejes ${ }^{\mathrm{a}}$, Anikó Borbás ${ }^{\mathrm{a}}$, Eszter Ostorházi ${ }^{\mathrm{c}}$, Ferenc Rozgonyi ${ }^{\mathrm{c}}$, Lieve Naesens ${ }^{\mathrm{d}}$, Pál Herczegh ${ }^{\mathrm{a}, *}$ \\ ${ }^{a}$ Department of Pharmaceutical Chemistry, Medical and Health Science Center, University of Debrecen, Egyetem tér 1, H-4010 Debrecen, Hungary \\ ${ }^{\mathrm{b}}$ Department of Organic Chemistry, University of Debrecen, Egyetem tér 1, H-4010 Debrecen, Hungary \\ ${ }^{\mathrm{c}}$ Microbiology Laboratory, Department of Dermatology, Venerology and Dermatooncology, Semmelweis University, Mária u. 41, H-1085 Budapest, Hungary \\ ${ }^{\mathrm{d}}$ Rega Institute for Medical Research, Katholieke Universiteit Leuven, B-3000 Leuven, Belgium
}

\section{A R T I C L E I N F O}

\section{Article history:}

Received 7 August 2012

Revised 18 September 2012

Accepted 22 September 2012

Available online 29 September 2012

\section{Keywords:}

Teicoplanin

Pseudoaglycon

Isoindole

Antibacterial

Antiviral

Influenza

\begin{abstract}
A B S T R A C T
The primary amino function of teicoplanin pseudoaglycon has been transformed into arylthioisoindole or benzoisoindole and glycosylthioisoindole derivatives, in a reaction with o-phthalaldehyde or naphtalene2,3-dicarbaldehyde and various thiols. All of the obtained semisynthetic antibiotics exhibited potent antibacterial activities against Gram-positive bacteria in the ng per ml concentration range. A few of them showed antiviral activity, in particular against influenza virus.
\end{abstract}

(c) 2012 Elsevier Ltd. All rights reserved.
Glycopeptide antibiotics vancomycin and teicoplanin are used in the treatment of serious Gram-positive bacterial infections that are resistant to other antibiotics. ${ }^{1}$ Due to the emergence and spread of glycopeptide-resistant enterococci (GRE) and glycopeptide intermediate-resistant Staphylococcus aureus (GISA), as well as teicoplanin-resistant Staphylococcus haemolyticus, ${ }^{2}$ there is an urgent need for new antibiotics active against resistant bacteria.

Nagarajan et al. reported on lipophilic $\mathrm{N}$-alkyl derivatives of glycopeptide antibiotics possessing high activity against vancomycinresistant bacteria. ${ }^{3}$ Later this observation led to the elaboration of the highly active subclass of lipoglycopeptides oritavancin, telavancin and dalbavancin. ${ }^{4}$ In the past few years we have synthesized a series of new derivatives of ristocetin aglycon and of teicoplanin pseudoaglycon exhibiting high antibacterial and, in some cases, robust ant-influenza virus activity. ${ }^{5}$ For the elucidation of the mechanism of biological action fluorescent isoindole- and benzoisoindole-fused aglycoristocetin derivatives have also prepared in this laboratory. ${ }^{6}$ The biological evaluation of these derivatives revealed that the introduction of the isoindole and benzoisoindole moieties into the $\mathrm{N}$-terminal position of the aglyc-

\footnotetext{
* Corresponding authors. Tel.: +36 52512900 22895; fax: +36 52512914 .

E-mail addresses: sipos.attila@pharm.unideb.hu (A. Sipos), herczeghp@gmail. com (P. Herczegh).
}

oristocetin molecule resulted in remarkable increase in the antibacterial and anti-influenza virus activity.

In order to get more information about the effect of (benzo)isoindole substituents on the biological activity of glycopeptide antibiotic derivatives, we decided to prepare a series of such derivatives from teicoplanin pseudoaglycon.

The starting pseudoaglycon 2 can be prepared from teicoplanin (1) by treatment with anhydrous hydrogen fluoride (Scheme 1$)^{7}$

The widely used three-component isoindole-formation reaction, involving the heteroring closure of o-phthalaldehyde (or its benzologs) with primary amine and a thiol, ${ }^{8}$ was chosen for the derivatization of the N-terminal of the glycopeptide. Reaction of the primary amino function of $\mathbf{2}$ with o-phthalaldehyde and various thiols such as (hetero)arylthiols, as well as 1-thio-d-glucopyranose or 1-thio- $N$-acetyl-d-glucosamine derivatives afforded the corresponding arylthio- (3), heteroarylthio- (4 and 5) and glycosylthioisoindole (9-12) derivatives in reasonably good yields. In a similar reaction, using naphtalene-2,3-dialdehyde instead of o-phthalaldehyde the appropriate benzoisoindole derivatives 6-8 were obtained, incorporating the $\mathrm{N}$-terminal nitrogen of the antibiotic into the new heteroring system (Table 1 ).

The new compounds 3-12 were characterized by HPLC, MALDITOF mass spectroscopy (key data and methods are included in the Supplementary material). The presence of the newly formed (benzo)isoindole moieties were confirmed by NMR spectroscopy. 


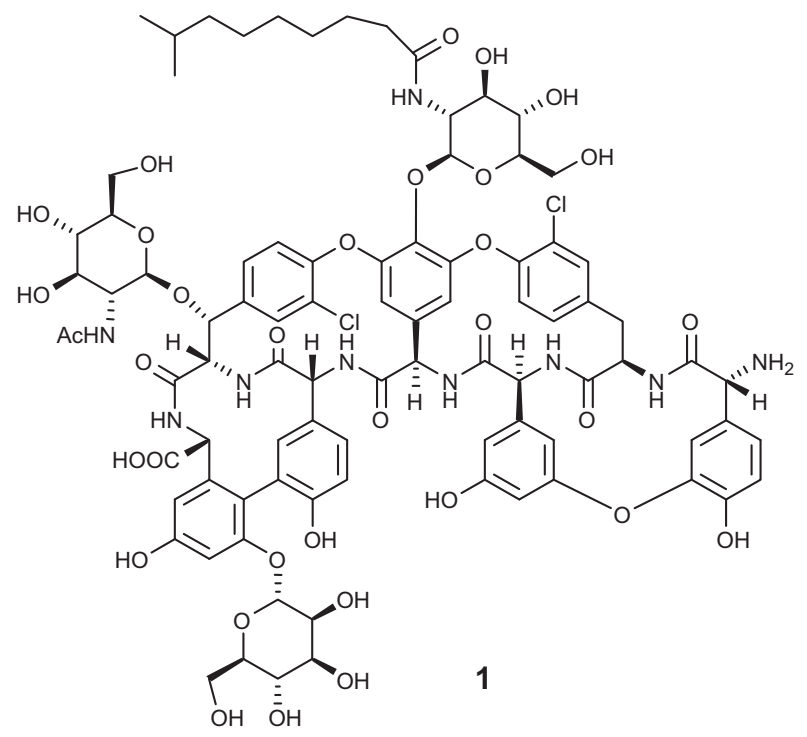
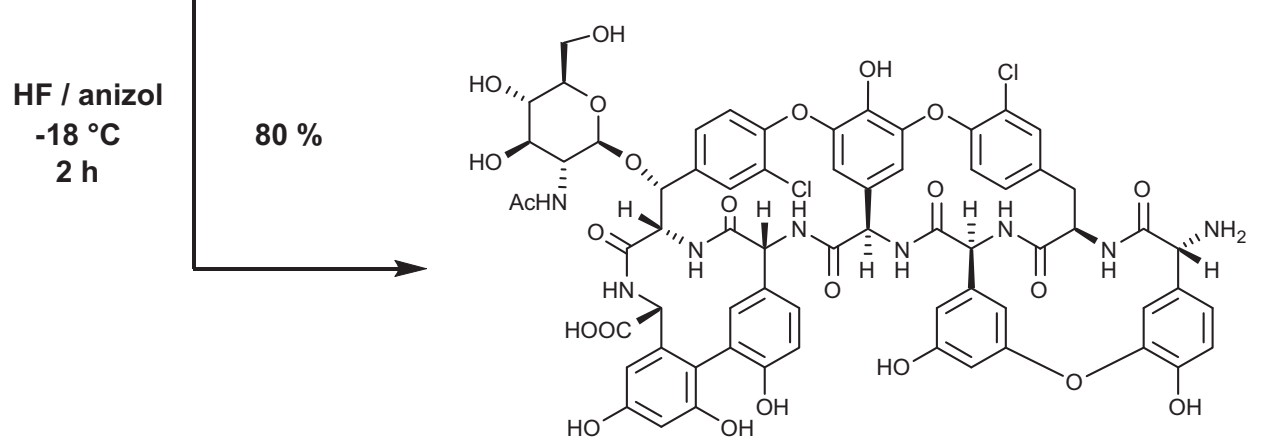

2

Scheme 1. Preparation of teicoplanin pseudoaglycon 2.

Table 1

Synthesis and structure of novel teicoplanin pseudoaglycon derivatives 3-12

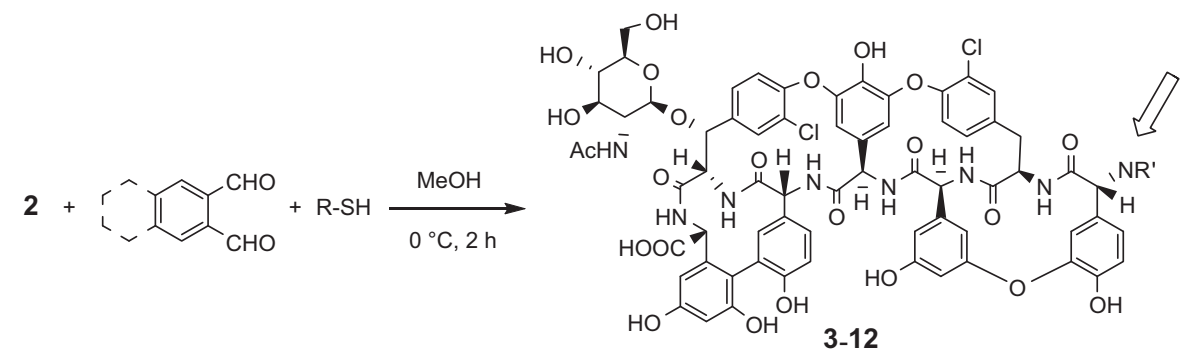

Product $\quad$ Starting dialdehyde $\quad$ Thiol reagent (R-SH)


Table 1 (continued)

\begin{tabular}{|c|c|c|c|c|c|}
\hline Product & Starting dialdehyde & Thiol reagent $(\mathrm{R}-\mathrm{SH})$ & Formed isoindole moiety $\left(\mathrm{R}^{\prime} \mathrm{N}-\right)^{\mathrm{a}}$ & Yield (\%) & $\log P^{\mathrm{t}}$ \\
\hline 5 & $\mathrm{CHO}$ & & & 49 & 7.95 \\
\hline 6 & $\mathrm{CHO}$ & & & 31 & 8.44 \\
\hline 7 & $\mathrm{CHO}$ & & & 62 & 6.47 \\
\hline 8 & $\mathrm{CHO}$ & & & 58 & 9.18 \\
\hline 9 & & & & 51 & 2.20 \\
\hline 10 & $\mathrm{CHO}$ & & & 72 & 6.25 \\
\hline 11 & & $\bar{N} H A c$ & & 49 & 3.53 \\
\hline 12 & $\mathrm{CHO}$ & & & 52 & 5.03 \\
\hline
\end{tabular}

a General procedure: $0.11 \mathrm{mmol}$ dialdehyde, $0.11 \mathrm{mmol}$ thiol in $3 \mathrm{~mL} \mathrm{MeOH}$ (protected from light, under argon) stirred for $20 \mathrm{~min}$ at $0{ }^{\circ} \mathrm{C}$. $0.05 \mathrm{mmol} 2$ in $3 \mathrm{~mL}$ MeOH added and stirred for $2 \mathrm{~h}$ at RT.

${ }^{\mathrm{b}} \log P$ values were calculated with ChemSketch $\log P$ add-on. ${ }^{9}$

Determination of the antibacterial activity of this series of compounds against a panel of Gram positive bacteria ${ }^{10}$ gave excellent results, as summarized in Table 2 . Almost all of the new derivatives exhibited better MIC and MBC values than the parent antibiotic teicoplanin.

The database of the European Committee on Antibacterial Susceptibility Testing (EUCAST) ${ }^{11}$ contains the MIC values for a wide range of bacteria and antimicrobial agents. These EUCAST data were aggregated from extended time periods and many countries. According to the data of EUCAST for 6105 Enterococcus faecalis strains, teicoplanin is effective in the MIC range of $0.06-2 \mu \mathrm{g} / \mathrm{mL}$. For our newly synthesized derivatives, the MIC values against Enterococcus faecalis were in the range of $0.0075-4 \mu \mathrm{g} / \mathrm{mL}$, either tested against the teicoplanin susceptible wild-type strain, or two teicoplanin resistant Enterococcus faecalis strains containing the vanA or vanB resistance genes. In comparison, the MIC values of teicoplanin against these three genotypes were $2 \mu \mathrm{g} / \mathrm{mL}$ (wild-type), 256 (vanA genotype) and $4 \mu \mathrm{g} / \mathrm{mL}$ (vanB genotype), respectively. EUCAST reported 566 observed cases of Staphylococcus aureus MRSA infections with successful teicoplanin treatment having the MIC values mostly between 0.25 and $2 \mu \mathrm{g} / \mathrm{mL}$. Against our Staphylococcus aureus MRSA strain, we found teicoplanin effective with an MIC value of $0.5 \mu \mathrm{g} / \mathrm{mL}$. Notably the new isoindole derivatives showed efficacy at much lower MIC values, that is $0.0075-1 \mu \mathrm{g} / \mathrm{mL}$. Against Staphylococcus aureus MSSA strains, teicoplanin was effective in the MIC range of $0.5-2 \mu \mathrm{g} / \mathrm{mL}$ (analysis from 571 reported cases). In our studies, the reference teicoplanin (1) was found to be active against an MSSA strain with an MIC of 


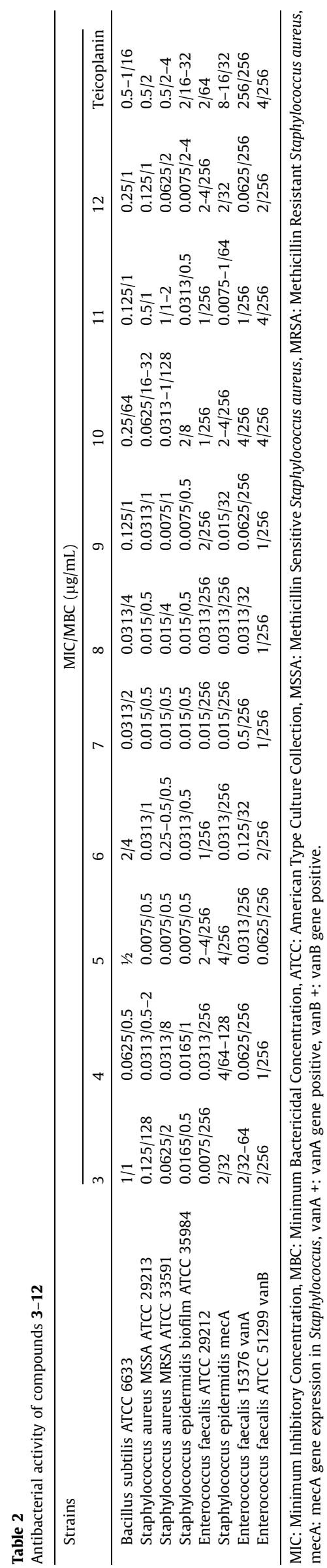

$0.5 \mu \mathrm{g} / \mathrm{mL}$, whereas the isoindole derivatives had lower MIC values in the range of $0.0075-0.5 \mu \mathrm{g} / \mathrm{mL}$. With regard to Staphylococcus epidermidis, MIC values for teicoplanin were typically between 0.25 and $16 \mu \mathrm{g} / \mathrm{mL}$, in the EUCAST database for 8578 cases. We determined the MIC values of teicoplanin and the isoindole derivatives against two $S$. epidermidis strains to be $2-8 \mu \mathrm{g} / \mathrm{mL}$ and $0.0075-4 \mu \mathrm{g} / \mathrm{mL}$, respectively. Compounds 3-12 proved to be very active against vancomycin and teicoplanin resistant enterococci, with some compounds displaying MIC values in the $\mathrm{ng} / \mathrm{ml}$ range. Overall, the most active compounds of the series were $\mathbf{6}$ and $\mathbf{7}$ benzoisoindole derivatives. Compound $\mathbf{9}$, containing d-glucosyl substituent with free hydroxyl groups displayed better activity than its acetylated counterpart. Although for obtaining an exact structure-activity relationship a detailed study involving a higher number of compounds is required, here it can be concluded that isoindole derivatisation of $\mathbf{2}$ led to much more potent antibacterials than the parent teicoplanin.

The anti-influenza virus activities and cytotoxic concentrations $^{12}$ of our products 3-12, in comparison to four antiviral reference agents, are summarized in Table 3.

With the exception of compounds $\mathbf{7}$ and $\mathbf{8}$, the new teicoplanin pseudoaglycon derivatives showed no anti-influenza virus activity at subtoxic concentrations. Compared to unsubstituted teicoplanin pseudoaglycon 2, which was found to possess weak anti-influenza A virus activity and no activity against B virus, the new heteroaromatic moiety was found to have crucial impact on the activity. For compound 7, a favorable selectivity index was noted, since its ratio of MCC to $\mathrm{EC}_{50}$ was 24 . The 2-S-heteroarylbenzoisoindole function at the $\mathrm{N}$-terminus of compounds $\mathbf{7}$ and $\mathbf{8}$ appeared to be responsible for this effect. From a comparison with compound $\mathbf{6}$, which has a 2-S-homoarylbenzoisoindole at the $\mathrm{N}$-terminus, it can be concluded that the presence of heteroatoms in the 2 -S-substituent may be advantageous. Most of our new derivatives displayed relatively high cytotoxicity in this assay in Madin Darby canine kidney cells, since the compound concentrations causing minimal alterations in cell morphology were $20 \mu \mathrm{M}$ or lower.

Besides this anti-influenza virus testing, compounds 2-13 were evaluated against a selected panel of DNA viruses as well as one RNA virus (vesicular stomatitis virus). The antiviral activity and cytotoxicity of 2-12 in human embryonic lung (HEL) fibroblasts ${ }^{13}$ are summarized in Table 4.

Table 3

Anti-influenza virus activity and cytotoxicity of compounds 2-12 in MDCK cell cultures

\begin{tabular}{lllll}
\hline \multirow{2}{*}{ Compounds } & \multicolumn{2}{l}{ Antiviral $\mathrm{EC}_{50}(\mu \mathrm{M})$} & $\mathrm{MCC}(\mu \mathrm{M})$ \\
\cline { 2 - 4 } & $\begin{array}{l}\text { Influenza A/H1N1 } \\
(\mathrm{A} / \mathrm{PR} / 8 / 34)\end{array}$ & $\begin{array}{l}\text { Influenza } \mathrm{A} / \mathrm{H} 3 \mathrm{~N} 2 \\
(\mathrm{~A} / \mathrm{HK} / 7 / 87)\end{array}$ & $\begin{array}{l}\text { Influenza B } \\
(\mathrm{B} / \mathrm{HK} / 5 / 72)\end{array}$ \\
\hline 2 & 23 & 17 & $>100$ & $\geqslant 100$ \\
3 & $>100$ & $>100$ & $>100$ & 4 \\
4 & $>100$ & $>100$ & $>100$ & 20 \\
5 & $>100$ & $>100$ & $>100$ & 4 \\
6 & $>100$ & $>100$ & $>100$ & $<0.8$ \\
7 & 0.54 & 0.54 & $>50$ & 13 \\
8 & $<4.9$ & 1.6 & $>100$ & 20 \\
9 & $>100$ & $>100$ & $>100$ & $<0.8$ \\
10 & $>100$ & $>100$ & $>100$ & 20 \\
11 & $>100$ & $>100$ & $>100$ & $<0.8$ \\
12 & $>100$ & $>100$ & $>100$ & 20 \\
Zanamivir & 1.6 & 4.8 & 23 & $>100$ \\
Ribavirin & 6.1 & 6.0 & 4.6 & 100 \\
Amantadine & 212 & 0.45 & $>500$ & $\geqslant 500$ \\
Rimantadine & 14 & 0.051 & $>500$ & 500
\end{tabular}

$\mathrm{EC}_{50}: 50 \%$ effective concentration, or concentration producing $50 \%$ inhibition of virus-inducedcytopathic effect, as determined by visual scoring. MCC: Minimum compound concentration that causes a microscopically detectable alteration of normal cell morphology. MDCK cells: Madin Darby canine kidney cells. 
Table 4

Antiviral activity and cytotoxicity of compounds 2-12 in HEL cell cultures

\begin{tabular}{lllllll}
\hline \multirow{2}{*}{ Compounds } & \multicolumn{5}{c}{ Antiviral $\mathrm{EC}_{50}(\mu \mathrm{M})$} & $\begin{array}{l}\text { MCC } \\
(\mu \mathrm{M})\end{array}$ \\
\cline { 2 - 6 } & $\begin{array}{l}\text { HSV- } \\
\text { KOS }\end{array}$ & $\begin{array}{l}\text { HSV- } \\
\text { K }\end{array}$ & $\begin{array}{l}\text { Vaccinia } \\
\text { virus }\end{array}$ & $\begin{array}{l}\text { Vesicular } \\
\text { stomatitis } \\
\text { virus }\end{array}$ & $\begin{array}{l}\text { HSV-1 } \\
\text { TK }^{-} \text {KOS } \\
\text { ACV }^{\mathrm{r}}\end{array}$ & \\
\hline 2 & $>100$ & $>100$ & $>100$ & $>100$ & $>100$ & $>100$ \\
3 & 9 & 9 & $>20$ & $>20$ & $\geqslant 20$ & $\geqslant 20$ \\
4 & 47 & 45 & $\geqslant 58$ & $>100$ & 50 & $>100$ \\
5 & 45 & 45 & 47 & $>100$ & 45 & $\geqslant 100$ \\
6 & $>20$ & $>20$ & $>20$ & $>20$ & $>20$ & 100 \\
7 & 40 & 27 & 10 & $>100$ & 45 & $\geqslant 100$ \\
8 & $>100$ & $>100$ & $>100$ & $>100$ & $>100$ & $>100$ \\
9 & 45 & 40 & 45 & 52 & $\geqslant 45$ & $\geqslant 100$ \\
10 & 40 & 11 & 45 & 48 & 40 & $\geqslant 100$ \\
11 & 47 & 45 & 47 & 52 & 45 & $\geqslant 100$ \\
12 & 40 & 40 & 45 & $>100$ & 45 & $>100$ \\
Brivudin & 0.024 & 198 & 10 & $>250$ & 50 & $>250$ \\
Cidofovir & 1.5 & 0.9 & 21 & $>250$ & 1.5 & $>250$ \\
Acyclovir & 0.14 & 0.14 & $\geqslant 250$ & $>250$ & 44 & $>250$ \\
Ganciclovir & 0.015 & 0.013 & $>100$ & $>100$ & 4 & $>100$ \\
\hline
\end{tabular}

HEL: human embryonic lung fibroblasts; HSV-1 KOS: herpes simplex virus type 1 strain KOS; HSV-2 G: herpes simplex virus type 2 strain G; $\mathrm{TK}^{-}$: thymidine kinasedeficient HSV-1 KOS strain resistant to acyclovir $\left(\mathrm{ACV}^{\mathrm{r}}\right) ; \mathrm{EC}_{50}: 50 \%$ effective concentration, or concentration required for $50 \%$ decrease of virus-induced cytopathogenicity. MCC: minimum compound concentration that causes a microscopically detectable alteration of normal cell morphology.

Whereas teicoplanin pseudoaglycon (2) was found to be inactive against these viruses, several of the isoindole and benzoisoindole derivatives 3-12 showed weak inhibitory effect, although their antiviral $\mathrm{EC}_{50}$ values were relatively high and in the same order of magnitude as the compound concentrations causing cytotoxicity. The 2-S-phenylisoindole derivatized glycopeptide $\mathbf{3}$ was the most active, in particular against herpes simplex virus. It is worthwhile to mention that the compound cytotoxicity in the HEL cells (Table 4) was much less pronounced compared to MDCK cells (Table 3 ).

In conclusion, we have extended the series of isoindole- and benzoisoindole-fused glycopeptides with the synthesis of a set of teicoplanin pseudoaglycon derivatives. These compounds were found to possess remarkably high antibacterial activity against a panel of Gram positive bacteria including some resistant strains. Almost all of the new derivatives exhibited better MIC and MBC values than the parent antibiotic teicoplanin. The antiviral tests of these (benzo)isoindoles showed mixed results. We were able to identify two active anti-influenza virus agents, but other RNA and DNA viruses were only weakly inhibited. On the basis of these promising antibacterial results further examinations will be performed in order to identify the mechanism of action.

\section{Acknowledgments}

The work is supported by the TÁMOP 4.2.1/B-09/1/KONV-20100007 project. The project is co-financed by the European Union and the European Social Fund. The work was also supported by the Hungarian Research Fund OTKA through Grants K 79126 , T-46186, OTKA-NKTH CK 77515, and NK 68578. L.N. acknowledges the technical assistance from Leentje Persoons and Wim van Dam, and the financial support from the Flemish Fonds voor Wetenschappelijk Onderzoek (FWO No. 9.0188.07) and the Geconcerteerde Onderzoeksacties (GOA/10/014).

\section{Supplementary data}

Supplementary data associated with this article can be found, in the online version, at http://dx.doi.org/10.1016/j.bmcl.2012. 09.079.

\section{References and notes}

1. Ashford, P.-A.; Bew, S. P. Chem. Soc. Rev. 2012, 41, 957.

2. Kristóf, K.; Kocsis, E.; Szabó, D.; Kardos, S.; Cser, V.; Nagy, K.; Hermann, P.; Rozgonyi, F. Eur. J. Clin. Microbiol. Infect. Dis. 2011, 30, 691. and references therein.

3. Nagarajan, R.; Schabel, A. A.; Occolowitz, J. L.; Counter, F. T.; Ott, J. L.; FeltyDuckworth, A. M. J. Antibiot. 1998, 42, 63.

4. (a) Nicolaou, K. C.; Boddy, C. N. C.; Bräse, S.; Winssinger, N. Angew. Chem., Int Ed. 1999, 38, 2096; (b) Kahne, D.; Leimkuhler, C.; Lu, W.; Walsh, C. Chem. Rev. 2005, 105, 425 .

5. (a) Sztaricskai, F.; Pintér, G.; Rőth, E.; Herczegh, P.; Kardos, F.; Rozgonyi, F.; Boda, Z. J. Antibiot. 2007, 60, 529; (b) Pintér, G.; Bereczki, I.; Batta, G.; Ötvös, R. Sztaricskai, F.; Rőth, E.; Ostorházi, E.; Rozgonyi, F.; Naesens, L.; Szarvas, M.; Boda, Z.; Herczegh, P. Bioorg. Med. Chem. Lett. 2010, 20, 2713; (c) Naesens, L.; Vanderlinden, E.; Rőth, E.; Jeko, J.; Andrei, G.; Snoeck, R.; Pannecouque, C.; Illyés, E.; Batta, G.; Herczegh, P.; Sztaricskai, F. Antiviral Res. 2009, 82, 89; (d) Vanderlinden, E.; Vanstreels, E.; Boons, E.; Ter Veer, W.; Huckriede, A.; Daelemans, D. Van Lommel, A. Rőth, E.; Sztaricskai, F; Herczegh, P. Naesens, L. J. Virol. 2012, 86, 9416; (e) Pintér, G.; Batta, G.; Kéki, S.; Mándi, A.; Komáromi, I.; Takács-Novák, K.; Sztaricskai, F.; Rőth, E.; Ostorházi, E.; Rozgonyi, F.; Naesens, L.; Herczegh, P. J. Med. Chem. 2009, 52, 6053.

6. Sipos, A.; Máté, G.; Rőth, E.; Borbás, A.; Batta, G.; Bereczki, I.; Kéki, S.; Jóna, I.; Ostorházi, E., Rozgonyi, F.; Vanderlinden, E., Naesens, L.; Herczegh, P. Eur. J. Med. Chem. 2012, submitted for publication.

7. Wanner, J.; Tang, D.; McComas, C. C.; Crowley, B. M.; Jiang, W.; Moss, J.; Boger, D. L. Bioorg. Med. Chem. Lett. 2003, 13, 1169.

8. (a) Simons, S. S.; Johnson, D. F. J. Org. Chem. 1978, 43, 2886; (b) García AlvarezCoque, M. C.; MedinaHernández, M. J.; Villanueva Camañas, R. M.; Mongay Fernández, C. Anal. Biochem. 1998, 178, 1.

9. www.acdlabs.com/resources/freeware/chemsketch/logp

10. Protocol for antibacterial studies: Sztaricskai, F.; Batta, G.; Herczegh, P.; Balázs, A.; Jekő, J.; Rőth, E.; Szabó, P. T.; Kardos, S.; Rozgonyi, F.; Boda, Z. J Antibiot. 2006, 59, 564

11. www.eucast.org.

12. Cell-culture based assays for determination of the inhibitory effect on influenza virus replication: Vanderlinden, E.; Göktas, F.; Cesur, Z.; Froeyen, M.; Reed, M. L.; Russell, C. J.; Cesur, N.; Naesens, L. J. Virol. 2010, 84 4277.

13. Protocols for broad-spectrum antiviral studies: Krečmerová, M.; Holy, A.; Pohl R.; Masojídková, M.; Andrei, G.; Naesens, L.; Neyts, J.; Balzarini, J.; De Clercq, E.; Snoeck, R. J. Med. Chem. 2007, 50, 5765. 